\title{
PGC-1 $\alpha$ Regulates Translocated in Liposarcoma Activity: Role in Oxidative Stress Gene Expression
}

\author{
Cristina Sánchez-Ramos, Alberto Tierrez, Oscar Fabregat-Andrés, ${ }^{2}$ Brigitte Wild, ${ }_{1}^{1}$ Fatima Sánchez-Cabo, \\ Alessandro Arduini, ${ }^{3}$ Ana Dopazo, and María Monsalve ${ }^{1,4}$
}

\begin{abstract}
Translocated in liposarcoma (TLS) is a poorly characterized multifunctional protein involved in the genotoxic response. TLS regulates gene expression at several steps, including splicing and mRNA transport, possibly connecting transcriptional and posttranscriptional events. Aims: In this study we aimed to idenfity molecular targets and regulatory partners of TLS. Results and Innovation: Here we report that TLS transcriptionally regulates the expression of oxidative stress protection genes. This regulation requires interaction with the transcriptional coactivator peroxisome proliferator activated receptor $\gamma$-coactivator $1 \alpha$ (PGC- $1 \alpha)$, a master regulator of mitochondrial function that coordinately induces the expression of genes involved in detoxification of mitochondrial reactive oxygen species (ROS). Microarray gene expression analysis showed that TLS transcriptional activity is impaired in the absence of PGC- $1 \alpha$, and is thus largely dependent on PGC- $1 \alpha$. Conclusion: These results suggest the existence of a regulatory circuit linking the control of ROS detoxification to the coordinated cross-talk between oxidative metabolism and the cellular response to genomic DNA damage. Antioxid. Redox Signal. 15, 325-337.
\end{abstract}

\section{Introduction}

$\mathbf{U}$ NTIL RECENTLY, the cellular responses to genomic DNA damage and to oxidative stress resulting from excessive mitochondrial reactive oxygen species (ROS) production have been considered as fundamentally separate. However, recent reports on key transcriptional sensors such as p53 indicate that some common regulatory networks may connect DNA damage to mitochondria and oxidative stress responses (55). How these two fundamental pathways for cell survival are connected is still poorly understood.

Translocated in liposarcoma (TLS; also called fused in sarcoma [FUS]) is a gene expression regulator recently shown to be involved in the cellular response to DNA damage. TLS was originally discovered as part of a fusion protein with the transcription factor $\mathrm{C} / \mathrm{EBP}$ homologous protein, deriving from a characteristic chromosomal translocation in human liposarcomas. TLS is part of the TET family of RNA-binding proteins, which also includes Ewing's sarcoma and TAF15/ TAFII68. TET proteins appear to function in at least three gene expression processes-transcription, splicing, and mRNA transport-and might also play a role in DNA repair. The amino terminus of all TET family members is rich in glutamine, serine, and glycine residues and can function as a transcriptional activation domain $(7,59)$. The most conserved region in TET proteins is an RNPtype RNA-binding domain (RBD) that directs sequence-specific RNA binding. The TET proteins carboxy-terminus contain RGG repeats that might increase RNA affinity that are thought to contribute to RNA binding and might also be the site of post-translational modifications that regulate RNA binding or protein-protein

\section{Innovation}

Although excessive ROS production results in DNA damage, the mechanisms that link ROS homeostasis to the genotoxic response are largely unknown. To investigate possible links between ROS detoxification mechanisms and DNA damage sensing, we conducted a yeast two-hybrid screen to identify PGC- $1 \alpha$-interacting partners. TLS was identified as a PGC- $1 \alpha$ cofactor. Further experiments showed that TLS is a direct transcriptional regulator of several oxidative stress protection genes, and that this regulation depends on TLS interaction with PGC- $1 \alpha$. Moreover, whole-genome gene expression microarray analysis showed that TLS transcriptional activity is markedly reduced in PGC- $1 \alpha^{-/-}$cells. These results support the notion that TLS links responses to DNA damage and oxidative stress to the metabolic control provided by PGC $-1 \alpha$.

\footnotetext{
${ }^{1}$ Fundación Centro Nacional de Investigaciones Cardiovasculares Carlos III, Madrid, Spain.

${ }^{2}$ Hospital General de Valencia, Valencia, Spain.

${ }^{3}$ Departamento de Fisiología, Facultad de Farmacia, Universidad de Valencia, Valencia, Spain.

${ }^{4}$ Instituto de Investigaciones Biológicas "Alberto Sols" (CSIC) Madrid, Spain.
} 
interactions (11), and a Cys2-Cys2 zinc finger (52) that folds with the RBD into protease-resistant structures, and is likely to participate in RNA binding (24). TET proteins can bind not only RNA but also single-stranded and possibly doublestranded DNA. TLS promotes D-loop formation, a process whereby a single strand of DNA invades and pairs with one of the strands of a double-stranded region of DNA, a process necessary for DNA repair and recombination $(5,8)$.

Several reports link TLS activity to the cellular response to DNA damage. TLS knockout mice have unstable genomes as a result of chromosomal pairing defects and enhanced sensitivity to radiation $(21,27)$. Conversely, cells lacking TLS do not undergo appropriate DNA repair, resulting in genomic instability. Two kinases activated by damaged DNA, c-ABL and ataxia telangiectasia mutated (ATM), target TLS $(17,39)$. TLS also interacts with the stress response transcription factor YB-1 (28). A recent report provided a mechanism for TLS activity, but also functionally connected DNA damage sensing, RNA binding, and transcriptional regulation of the first fully characterized TLS transcriptional target, cyclin D1. The authors showed that activation of TLS in response to DNA damage can cause TLS to bind noncoding RNA transcripts that originate upstream of the cyclin D1 promoter. This binding facilitates the recruitment of TLS to the cyclin D1 promoter, resulting in transcriptional inactivation and subsequent cell cycle arrest (56).

A major cause of DNA damage is oxidative stress resulting from inefficient detoxification of mitochondrial ROS, suggesting the possibility of regulatory cross-talk between the oxidative stress response and the sensing of DNA damage. The transcriptional coactivator peroxisome proliferator activated receptor $\gamma$-coactivator $1 \alpha(\mathrm{PGC}-1 \alpha)$ is a master regulator of oxidative metabolism and mitochondrial function (20) that regulates expression of a set of genes involved in detoxification of mitochondrial ROS (54). The physiological role of PGC- $1 \alpha$ is particularly well characterized in liver, where the induction of PGC- $1 \alpha$ expression is a critical regulatory event leading to the activation of energy metabolic pathways that serve to increase ATP production and exert homeostatic control, especially in the context of fasting $(30,43,48,50)$.

\section{Results}

\section{TLS interacts with and coactivates PGC-1 $\alpha$}

We aimed to identify proteins that modulate the activity of PGC- $1 \alpha$ on oxidative stress protection genes. To identify candidate PGC- $1 \alpha$ cofactors we used the C-terminal domain (CTD; aa 580-797) as bait in a yeast two-hybrid screen of a human cDNA library. The PGC- $1 \alpha$ CTD mediates the interaction of PGC- $1 \alpha$ with FoxO3a, its DNA-binding partner in the regulation of oxidative stress genes (37). Of 32 positive clones, three were identified as TLS. TLS is an ubiquitiously expressed multifunctional protein proposed to have transcriptional cofactor activity $(19,41,53,56)$ and to orchestrate the cell response to DNA damage (27). The potential of TLS as a transcriptional cofactor and its link to DNA damage prompted our further studies.

To confirm direct interaction of TLS with PGC- $1 \alpha$ and to map the domains of PGC- $1 \alpha$ involved, we generated a glutathione-S-transferase (GST)-TLS fusion protein and tested its ability to pull down $\left[{ }^{35} \mathrm{~S}\right]$-radiolabeled PGC- $1 \alpha$ or its CTD mutant versions $\Delta \mathrm{RRM}(\Delta 677-710), \Delta \mathrm{SR}(\Delta 564-634), \Delta \mathrm{SR} /$
$\Delta R R M(\Delta 564-710)$, and $\Delta$ CTD (1-564) (34). TLS pulled down PGC- $1 \alpha$, and this interaction was preserved in the $\Delta R R M$, $\Delta S R$, and $\Delta S R / \Delta R R M$ mutants, indicating that TLS directly binds PGC- $1 \alpha$ in vitro and that this interaction does not require the RBD or the serine-arginine rich region. TLS did not pull down the PGC- $1 \alpha-\Delta$ CTD mutant, confirming the yeast two hybrid screen and showing that there are no additional TLS binding sites outside the PGC- $1 \alpha$-CTD domain (Supplementary Fig. S1; Supplementary Data available online at www .liebertonline.com/ars).

To identify the TLS domain that interacts with PGC- $1 \alpha-$ CTD, we performed the reverse pull down assay, using a GSTPGC- $1 \alpha-C$ TD fusion protein (37), to bind in vitro generated $\left[{ }^{35} \mathrm{~S}\right]$-radiolabeled TLS proteins. We generated two complementary TLS fragments, one corresponding to the N-terminal domain (NTD) (1-275 aa) and another corresponding to the CTD (residues 269-525) (11). Although PGC-1 $\alpha$-CTD pulled down TLS-CTD, we detected no binding of PGC- $1 \alpha-C$ TD to TLS-NTD (Fig. 1A). To map the binding site within TLS-CTD, we generated a series of TLS C-terminal deletions. Each deleletion removed an additional TLS subdomain. Deletion of the C-terminal-most 52 amino acids of TLS (corresponding to the third RGG domain [RGG3]) completely abolished binding (Fig. 1B). RGG domains are rich in Arg-Gly-Gly triplets and are proposed to regulate the specificity of adjacent RBDs (RNA recognition motif [RRM]) $(11,29)$, but have also been shown to engage in protein-protein interactions $(10,13)$. We therefore conclude that TLS interacts with PGC- $1 \alpha$ directly through its C-terminal RGG domain.

To determine whether TLS and PGC- $1 \alpha$ form a stable complex in cells, we transiently cotransfected 293T cells with Flag-tagged TLS together with HA-tagged full-length PGC-1 $\alpha$ or its CTD variants. TLS was detected in PGC- $1 \alpha$ immunoprecipitates in cells expressing full-length PGC- $1 \alpha$ and all mutant variants except PGC-1- $\Delta$ CTD (Fig. 1C). That this interaction occurs normally in cells and was not a consequence of forced TLS/PGC- $1 \alpha$ expression was confirmed in primary hepatocytes. TLS was detected in PGC- $1 \alpha$ coimmunoprecipitated material (Fig. 1D). These findings confirm the in vitro interaction assays and support the idea that PGC- $1 \alpha$ and TLS interact in living cells, and that the interaction requires the $\mathrm{C}$ terminal 87 PGC- $1 \alpha$ residues but not the RRM and SR (protein domain rich in Ser and Arg) motifs.

We next tested whether TLS binding modulates PGC- $1 \alpha$ transcriptional activity. $\mathrm{TLS}^{-/-}$and $\mathrm{TLS}^{+/+}$mouse embryonic fibroblasts (MEFs) were cotransfected with pGal4DBD-PGC- $1 \alpha$ (which encodes PGC- $1 \alpha$ fused to the Gal4 DNA binding domain) and the luciferase reporter plasmid 5xUAS-Luc (which contains 5 copies of the Gal4 binding site [5xUAS] in its promoter). PGC- $1 \alpha$ transcriptional activity was lower in $\mathrm{TLS}^{-/-}$cells (Fig. 1E). This decreased activity was rescued by cotransfection with full-length TLS (but not the TLS- $\Delta 1$ mutant), supporting the idea that TLS is a direct transcriptional coactivator of PGC- $1 \alpha$ (Fig. 1E). Similar results were obtained in the rat hepatoma cell line FAO, suggesting that this is not a cell-type-specific phenomenon (Supplementary Fig. S2).

\section{TLS regulates oxidative stress protection genes}

TLS has been shown to orchestrate the cellular response to DNA damage, which can result from oxidative stress. To in- 
FIG. 1. Peroxisome proliferator activated receptor $\gamma$-coactivator $1 \alpha \quad($ PGC-1 $\alpha)$ interacts with translocated in liposarcoma (TLS). (A, B) Glutathione-S-transferase (GST) pull down mapping of the interaction domains of PGC$1 \alpha$ and TLS. GST fusion proteins were immobilized on glutathione beads and incubated with ${ }^{35}$ S-labeled protein fragments. After extensive washing, interacting ${ }^{35}$ S-labeled proteins were gelseparated and detected by autoradiography. (A) Interaction of GST-PGC- $1 \alpha-C T D$ with full-length TLS and TLSNTD and TLS-CTD fragments. (B) Interaction of GSTPGC- $1 \alpha-C T D$ with TLS Cterminal deletion fragments. (C) TLS and PGC- $1 \alpha$ interaction in cells. 293T cells were transiently cotransfected with Flag-tagged TLS together with HA-tagged full-length PGC- $1 \alpha$ or the indicated Cterminal domain (CTD) variants. Anti-HA immunoprecipitation (IP) was used to test interaction with TLS. (D) Coimmunoprecipitation of endogenous TLS with PGC$1 \alpha$-specific antibodies in primary hepatocytes. (E) Left panel: Mammalian two-hybrid assay of the modulation of PGC-1 $\alpha$ activity by TLS. TLS TL $^{+/}$and TLS ${ }^{-/-}$ mouse embryonic fibroblasts (MEFs) were cotransfected with the Gal4 luciferase reporter plasmid 5xUAS-Luc and the indicated amounts of Gal4-DBD-PGC- $1 \alpha$ (encoding PGC- $1 \alpha$ fused to the DNA binding domain of Gal4 to provide a DNA tethering domain). Luciferase activity was determined $24 \mathrm{~h}$ post-transfection. Right panel: Rescue of PGC-1 $\alpha$ transcriptional activity in TLS ${ }^{-/-}$MEFs $^{-}$ by cotransfection with a TLS, but not a TLS- $\Delta 1$, expression vector. The asterisks indicate that the luciferase signal is significantly higher than that obtained for TLS alone. Data are means \pm SD. $\left(^{*}\right) p \leq 0.05$.

vestigate whether TLS plays a role in the regulation of oxidative stress protection genes previously shown to be PGC- $1 \alpha$ targets, we infected FAO cells with a recombinant adenovirus encoding TLS (Ad-T) or a control adenovirus (Ad). Analysis of mRNA and protein expression showed that overexpression of TLS induced the expression of all oxidative stress genes tested: Mn superoxide dismutase (MnSOD), catalase, peroxiredoxins 3 and 5 (Prx3 and Prx5), thioredoxin 2 (Trx2), thioredoxin reductase 2 (TR2), and uncoupling protein 2 (UCP-2) (Fig. 2A, B). To test if these genes were direct targets of TLS, we carried out chromatin immunoprecipitation (ChIP) assays using primers directed to promoter regions previously shown to recruit PGC- $1 \alpha$ in human cells (54). These experiments showed association of TLS with the promoter regions of MnSOD, Prx3, Prx5, catalase, and UCP-2 (Fig. 2C). Next, we tested the impact of TLS on ROS accumulation. Ad-T- or Ad-infected FAO cells were loaded with the ROS probe 5chloromethyl-2' 7'-dichlorodihydrofluorescein diacetate acetyl ester (CM- $\left.\mathrm{H}_{2} \mathrm{DCFDA}\right)$. ROS levels were estimated from the fluorescence signal of the $\mathrm{CM}-\mathrm{H}_{2}$ DCFDA oxidation product
CM-DCF. ROS were significantly lower in FAO cells overexpressing TLS, suggesting a more active detoxification system in these cells (Fig. 2D).

Metabolic oxidative stress agents such as $\mathrm{H}_{2} \mathrm{O}_{2}$ and high glucose induce the mitochondrial apoptotic cascade (which involves activation of caspase-3) in hepatocytes of different origins, including FAO cells $(22,49)$. To investigate the importance of TLS activity for cell survival, we monitored apoptotic cell death in Ad-T- or Ad-infected FAO cells under oxidative stress conditions. TLS overexpression reduced the activity of caspase- 3 in response to exposure to $150 \mu \mathrm{M} \mathrm{H}_{2} \mathrm{O}_{2}$ (Fig. 2E). This result suggests that TLS protects FAO cells from $\mathrm{H}_{2} \mathrm{O}_{2}$-induced apoptosis, probably by increasing the cellular detoxification capacity.

We then investigated the influence of endogenous TLS on the mitochondrial detoxification system. First, we compared the expression of the panel of oxidative stress protection genes in $\mathrm{TLS}^{+/+}$and $\mathrm{TLS}^{-/-}$MEFs. TLS-deficient MEFs had lower mRNA levels of all the genes tested (Fig. 3A). Western blotting (WB) confirmed reduced protein expression. The exception 

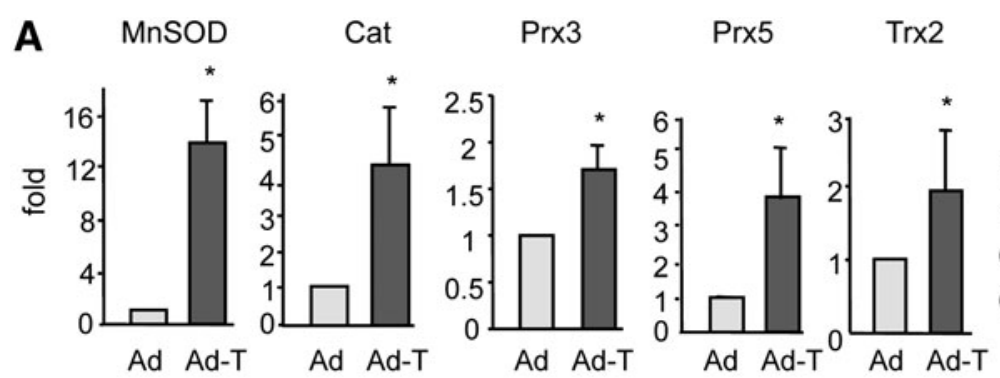

TrxR2

UCP-2

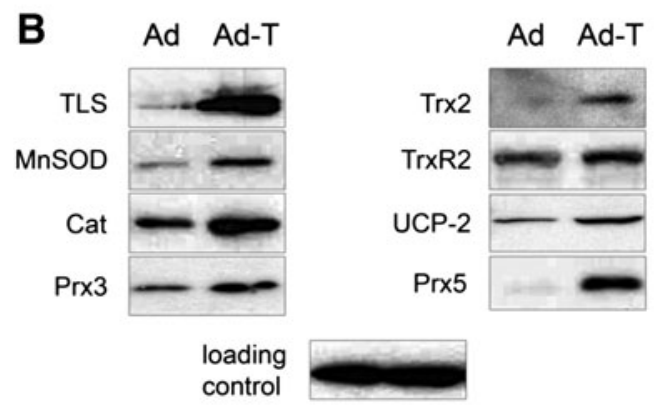

C

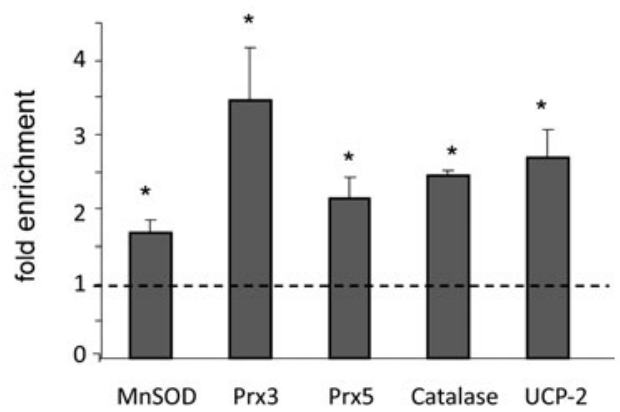

D

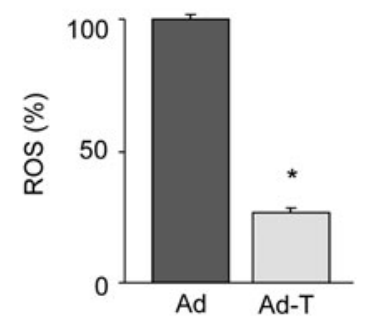

E

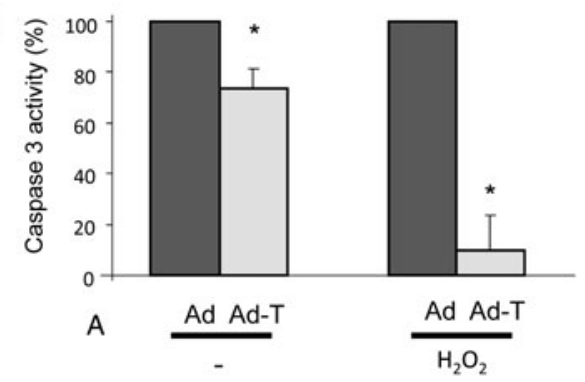

FIG. 2. TLS regulates oxidative stress protection gene expression. (A) Quantitative PCR of retro transcribed cDNA (qRTPCR) analysis of the expression of genes involved in oxidative stress protection in FAO cells infected with Ad-TLS (Ad-T). Expression is shown as the fold induction above the level in cells infected with control adenovirus (Ad). 18S RNA was used as a loading control. Control samples were assigned the value of 1. (B) Western blot (WB) analysis of oxidative stress protection proteins in FAO cells infected with Ad-T or Ad. (C) Chromatin immunoprecipitation (ChIP) analysis of TLS binding to the promoter regions of oxidative stress protection genes in FAO cells infected with Ad-T. $\beta$-actin was used as a negative control. Control samples were assigned the value of 1. (D) Flow cytometry analysis of intracellular reactive oxygen species (ROS) levels. Ad-T or Ad-infected FAO cells were loaded with $\mathrm{CM}-\mathrm{H}_{2} \mathrm{DCFDA}$, and ROS levels estimated from the fluorescence signal of the CM- $\mathrm{H}_{2}$ DCFDA oxidation product CM-DCF. ROS levels in control samples were assigned the value of $100 \%$. (E) Determination of caspase-3 activity in whole-cell extracts of FAO cells infected with AdT or Ad and treated for the indicated times with $150 \mu \mathrm{M} \mathrm{H}_{2} \mathrm{O}_{2}$. The signal for control cells was assigned the value of $100 \%$. The caspase inhibitor Z-VAD was used as a positive control. Data are means \pm SD. ${ }^{*} p \leq 0.05$.

was TrxR2, whose mRNA levels were only marginally reduced and whose protein expression was in fact increased (Fig. 3B). Reduced expression of oxidative stress protection genes was reflected in higher basal levels of ROS in $\mathrm{TLS}^{-/-}$ MEFs (Fig. 3C). Similar results were obtained in primary hepatocytes expressing TLS-specific small interference RNA (siRNA). WB confirmed reduced protein expression for all proteins tested (including TrxR2) (Fig. 3). Together, these results indicate that TLS is an important regulator of ROS detoxification and is necessary for the maintenance of the basal expression of oxidative stress protection genes.

\section{TLS cooperates with PGC-1 $\alpha$ in the regulation of oxidative stress protection genes}

The results presented in Figures 1 and 2 show that TLS is a cofactor of PGC- $1 \alpha$ transcriptional activity and that TLS and
PGC- $1 \alpha$ regulate a common group of oxidative stress protection genes. Most strikingly, the ChIP analysis (Fig. 2C) (54) revealed that these factors associate with the same or overlapping promoter regions. We therefore investigated the potential cooperation between TLS and PGC- $1 \alpha$ in the regulation of oxidative stress protection genes.

FAO cells were infected with Ad-T alone or together with Ad-P, which encodes PGC- $1 \alpha$. The multiplicity of infection (moi) was reduced to a quarter of that in the previous assays to facilitate detection of cooperative effects. Simultaneous expression of both TLS and PGC- $1 \alpha$ resulted in cooperative induction of mRNA and protein expression of all the oxidative stress genes studied both at normal glucose $(5 \mathrm{mM})$ and at high glucose $(25 \mathrm{mM})$ to increase mitochondrial ROS production (Fig. 4A, B). For MnSOD, catalase, Prx5, and TR2, high glucose induced a higher level of cooperativity, but did not fundamentally alter the induction of Trx2 and UCP-2 and 
A

A $\square$ TLS* $\square$ TLS* Ad-shC $\square$ Ad-shTLS

FIG. 3. TLS regulates oxidative stress protection gene expression. (A) qRT-PCR analysis of the mRNA expression of oxidative stress protection genes in $\mathrm{TLS}^{+/+}$ and $\mathrm{TLS}^{-/}$MEFs (left panel) or in primary hepatocytes infected with Ad-TLS-specific shRNA (shTLS) (encoding TLS sh-RNA) or the corresponding control (right panel). 18S RNA was used as loading control. (B) WB analysis of oxidative stress protection proteins in $\mathrm{TLS}^{+/+}$and TLS $^{-/-}$MEFs (left panel) or in primary hepatocytes infected with Ad-shTLS or the corresponding control (right panel). $\beta$-actin was used as loading control. (C) Intracellular ROS levels in TLS $\mathrm{TL}^{+/+}$and $\mathrm{TLS}^{-/-}$ MEFs (left panel) or in primary hepatocytes infected with AdshTLS or the corresponding control (right panel). Levels in $\mathrm{TLS}^{+/+}$and Ad-shControl cells were assigned the value of $100 \%$. Data are means \pm SD. ${ }^{*} p \leq 0.05$.
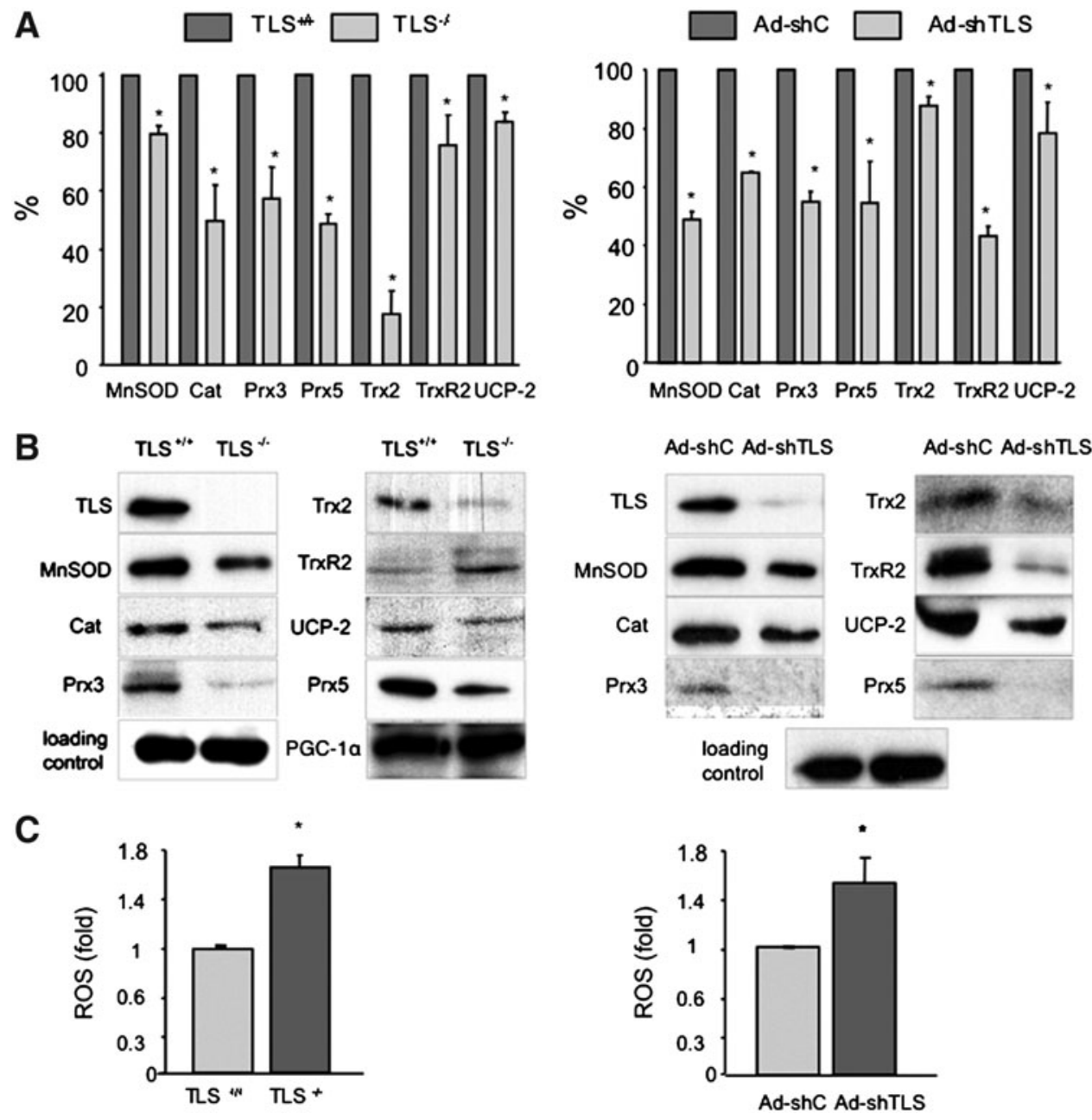

reduced the induction of Prx3 mRNA. The cooperative effect of coexpressing TLS and PGC- $1 \alpha$ was also seen in a greater reduction of ROS production than in cells expressing either protein alone (Fig. 4C). These results support the hypothesis that TLS and PGC- $1 \alpha$ regulate cooperatively the cellular ROS protection systems.

\section{$T L S$ and $P G C-1 \alpha$ are mutually required for the regulation of oxidative stress gene expression}

We next tested whether TLS is necessary for the regulation of oxidative stress genes by PGC- $1 \alpha$. We infected immortalized $\mathrm{TLS}^{+/+}$and $\mathrm{TLS}^{-/-}$MEFs with Ad-P or control Ad and monitored the induction of oxidative stress gene mRNA and protein expression. In TLS $^{+/+}$MEFs, PGC- $1 \alpha$ overexpression induced slight but statistically significant increases in the mRNA expression of all the target genes studied (Fig. 5A, left panel). This was accompanied by marked increases in the protein expression of catalase and Trx 2 and milder increases in UCP-2, MnSOD, and Prx3 (Fig. 5B, left panel). Prx5 and TR2 expression was not altered (results not shown). In $\mathrm{TLS}^{-/-}$ MEFs, PGC- $1 \alpha$ capacity to induce ROS protection genes was drastically reduced. At the mRNA level, only MnSOD induction could be detected. The results were confirmed by WB (Fig. 5A, B, left panels). PGC-1 $\alpha$ overexpression was similarly unable to reduce ROS levels in $\mathrm{TLS}^{-/-}$MEFs (Fig. 5C),

further confirming that PGC- $1 \alpha$ cannot compensate for TLS deficiency.

To determine whether TLS-mediated induction of oxidative protection genes was reciprocally dependent on PGC- $1 \alpha$, we tested the effect of TLS silencing in primary hepatocytes isolated from PGC- $1 \alpha^{+/+}$and PGC- $1 \alpha^{-/-}$mice. PGC- $1 \alpha^{-/-}$ cells have lower expression of several oxidative stress protection genes and increased ROS levels $(37,51)$. Adenovirally expressed TLS-specific shRNA (shTLS) reduced mRNA and protein expression of oxidative protection genes in PGC- $1 \alpha^{+/+}$ hepatocytes. This ability was either severely reduced or completely abolished in PGC- $1 \alpha^{-/-}$hepatocytes for all genes studied (Fig. 5A, B, right panels). Analysis of ROS levels showed that although TLS knockdown increased ROS in PGC$1 \alpha^{+/+}$hepatocytes, it had only a marginal effect in PGC- $1 \alpha^{-/-}$ hepatocytes (Fig. 5D), further supporting the notion that TLS activity is dependent on PGC- $1 \alpha$. ChIP analysis showed that the association of TLS with the promoter regions of Prx3 and Prx5 was drastically reduced in PGC- $1 \alpha^{-/-}$hepatocytes. This result suggests that association of TLS to these promoters is mediated by the interaction of TLS with PGC- $1 \alpha$ (Fig. 5E).

\section{TLS transcriptional activity is dependent on PGC-1 $1 \alpha$}

Apart from the oxidative stress response genes analyzed here, the only validated transcriptional target of TLS is cyclin 
A

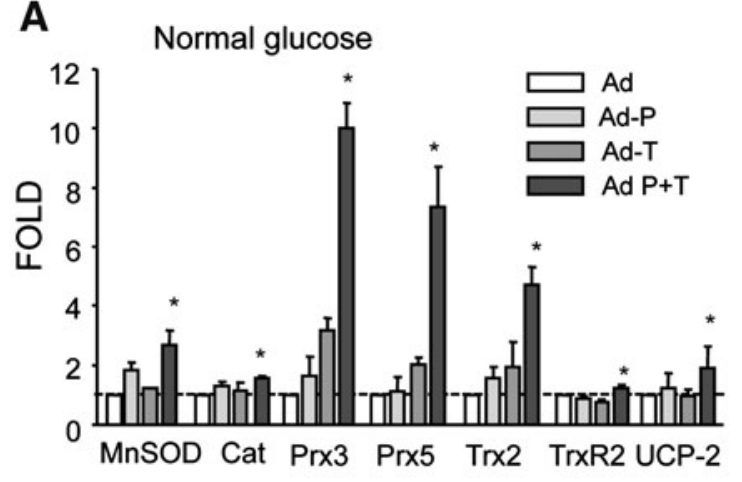

B

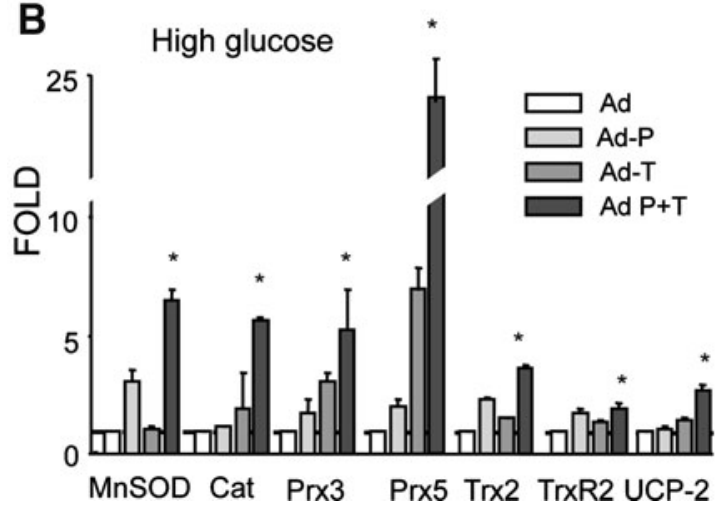

C

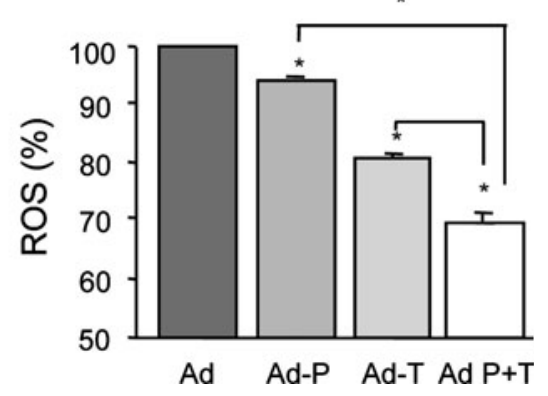

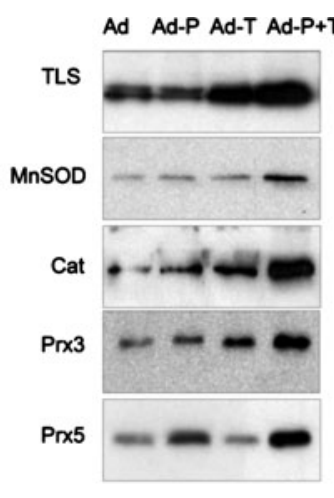

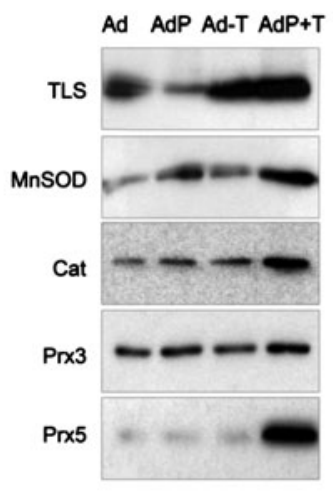

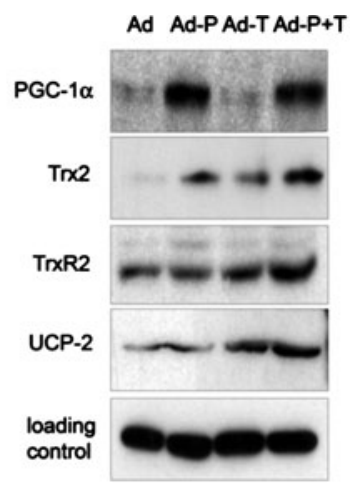

Ad AdP Ad-T Ad P+T

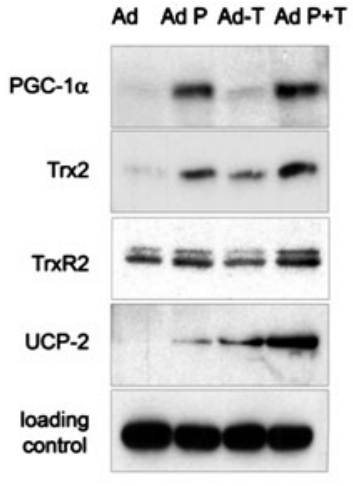

FIG. 4. TLS and PGC-1 $\alpha$ cooperatively induce detoxification genes in FAO cells. (A, B) qRT-PCR and WB analysis of the expression of oxidative stress protection genes in FAO cells infected with Ad-PGC-1 $\alpha$ (Ad-P), Ad-TLS (Ad-T), or both (Ad-P + T). mRNA expression is shown as the fold induction above the level in cells infected with control Ad. Control samples were assigned the value of 1 . Cells were cultured in $5 \mathrm{mM}$ glucose (A) and $25 \mathrm{mM}$ glucose (B). (C) Intracellular ROS levels in cells infected as in (A, B) and loaded with $\mathrm{CM}-\mathrm{H}_{2}$ DCFDA. ROS levels in control samples were assigned the value of $100 \%$. Data are means \pm SD. ${ }^{*} p \leq 0.05$.

These data suggest that TLS activity is significantly reduced in the PGC-1 $\alpha^{-/-}$hepatocytes and also that the dependency of TLS on PGC- $1 \alpha$ is more important for genes that are positively regulated by TLS. However, TLS seems to have some PGC- $1 \alpha$-independent transcriptional activities and TLS regulation of a small group of genes actually seems to require PGC-1 $\alpha$ inactivation (Fig. 6A).

Supporting this conclusion, scatter plot analysis showed that, on average, if we consider the genes regulated by shTLS only in PGC- $1 \alpha^{+/+}$hepatocytes (1623), the fold change in expression induced by shTLS in PGC- $1 \alpha^{+/+}$hepatocytes is two times bigger than in PGC- $1 \alpha^{-/-}$hepatocytes $\left(R^{2}=0.86\right.$ and Fig. 6B, blue dots). Similarly, if we consider the genes regulated by shTLS only in PGC- $1 \alpha^{-/-}$hepatocytes (201), for those genes the fold change in expression induced by shTLS in PGC- $1 \alpha^{-/-}$hepatocytes is two times bigger than in PGC$1 \alpha^{+/+}$hepatocytes, although the dispersion is larger $\left(R^{2}=0.78\right.$ and Fig. 6B, violet dots). Finally, genes that were differentially regulated by shTLS in both PGC- $1 \alpha^{+/+}$and PGC- $1 \alpha^{-/-}$hepatocytes (955) had on average the same change in expression 
A
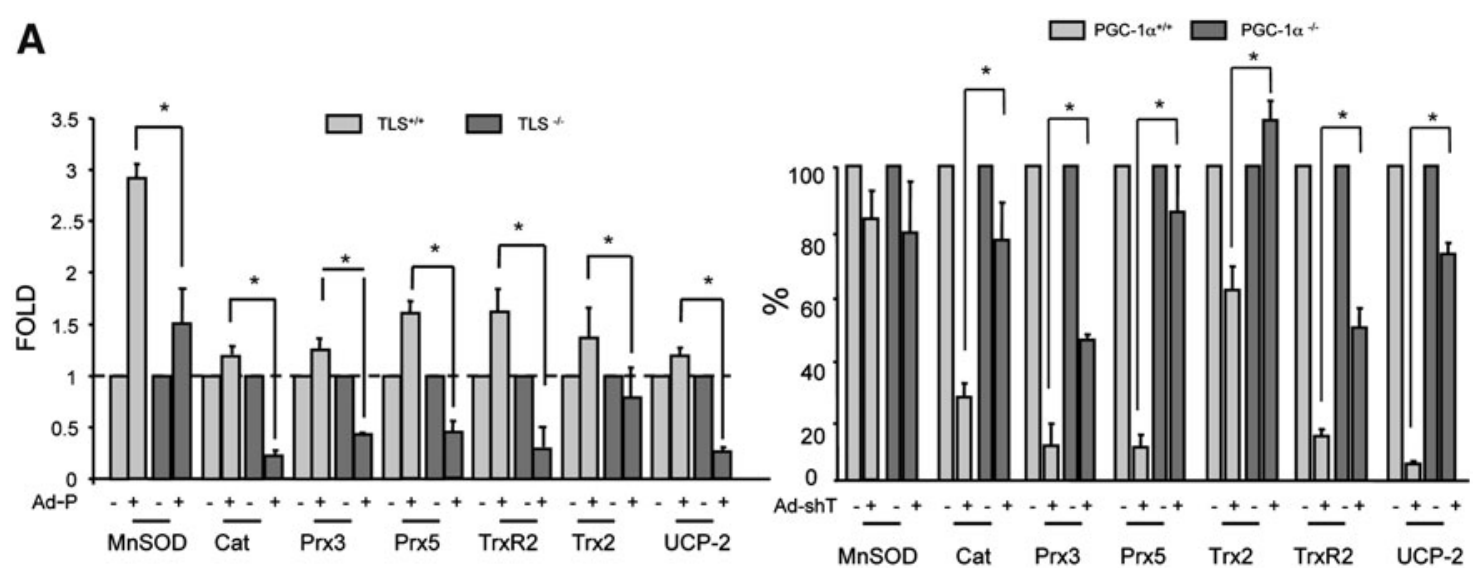

B
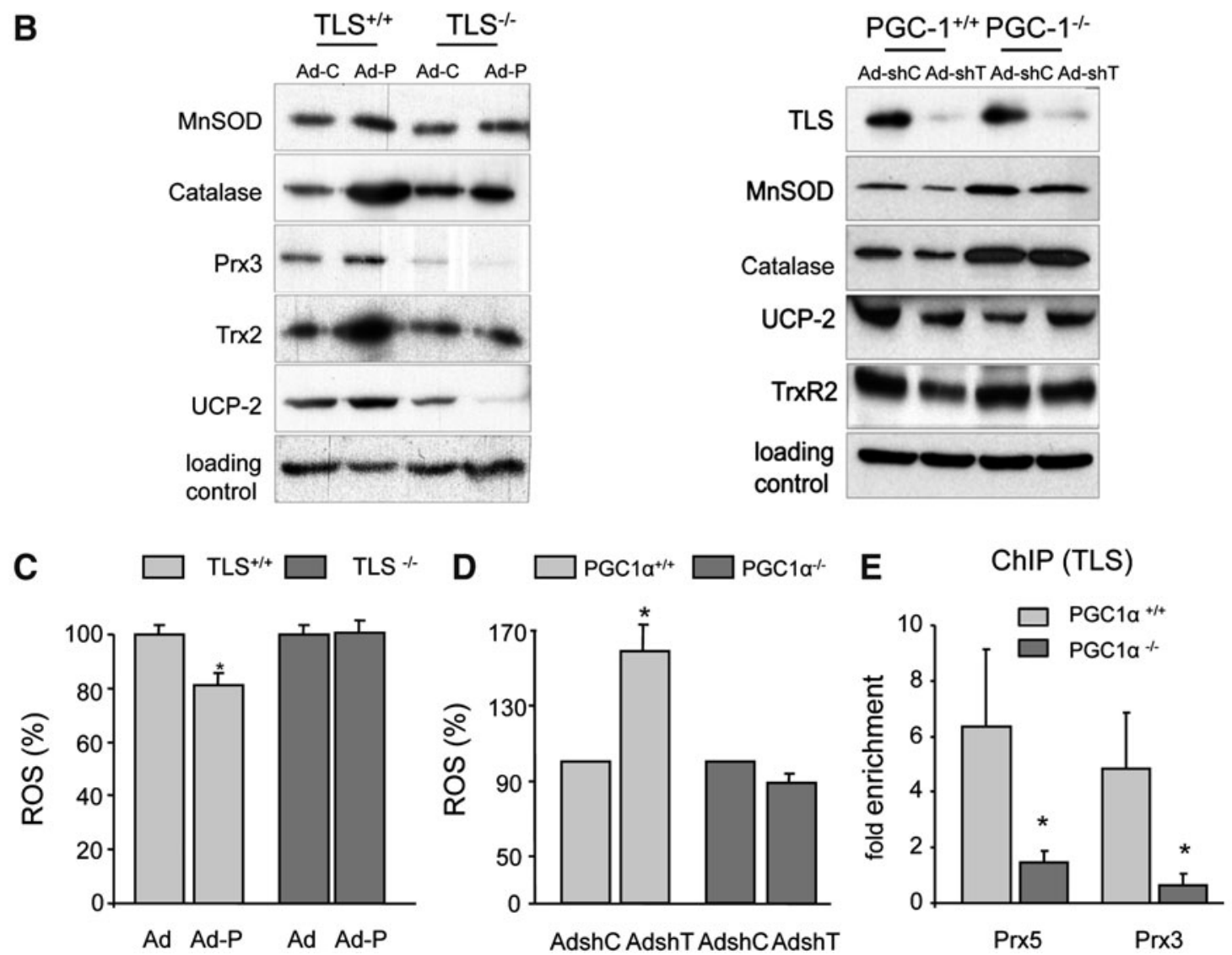

FIG. 5. PGC-1 $\alpha$ and TLS are mutually dependent in the regulation of oxidative stress protection genes. (A, B) $q R T-P C R$ and WB analysis of the induction of oxidative stress protection genes in TLS ${ }^{+/+}$and TLS ${ }^{-/-}$MEFs that were infected with PGC-1 $\alpha$ (Ad-P) (left panel) or primary hepatocytes from PGC-1 $\alpha^{+/+}$and PGC-1 $\alpha^{-/-}$mice infected with Ad-shTLS or the corresponding control. mRNA expression is shown as the fold induction above the level in cells infected with control Ad (left panel) or the relative \% (right panel). Control samples were assigned the value of 1 or $100 \%$. (C, D) Intracellular ROS levels in cells infected as in (A, B) and loaded with CM- $\mathrm{H}_{2}$ DCFDA. ROS levels in control samples were assigned the value of $100 \%$. (E) ChIP analysis of TLS binding to the promoter regions of peroxiredoxins 5 and $3(\operatorname{Pr} x 5$ and $\operatorname{Pr} x 3)$ in PGC- $1 \alpha^{+/+}$and PGC$1 \alpha^{-/-}$hepatocytes. The CDS of $\beta$-actin was used as a negative enrichment control. Data are means \pm SD. ${ }^{*} p<0.05$.

in response to TLS knock down in PGC- $1 \alpha^{+/+}$and PGC$1 \alpha^{-/-}$hepatocytes $\left(R^{2}=0.96\right.$ and Fig. $6 \mathrm{~B}$, black dots).

To identify relevant functions regulated by TLS and their dependency on PGC- $1 \alpha$, we carried out gene functional analysis of TLS-regulated genes using the Ingenuity software. The analysis showed that TLS regulates the same functional groups in PGC- $1 \alpha^{+/+}$and PGC- $1 \alpha^{-/-}$hepatocytes, further supporting the idea that TLS has essentially the same but reduced activities in the absence of PGC- $1 \alpha$. The analysis showed that TLS (like PGC-1 $\alpha$ ) regulates an important number of genes involved in the control of cellular metabolism. This result supports the notion of a strong functional association of TLS and 


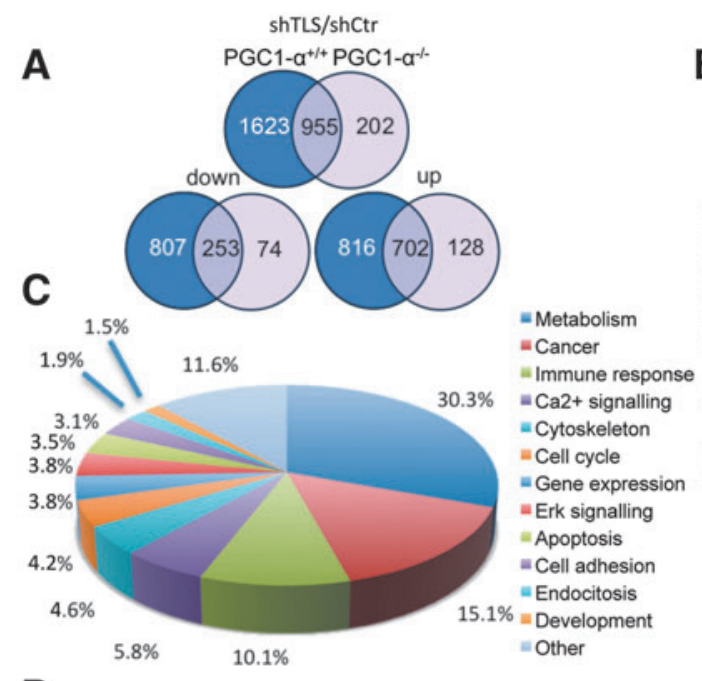

D

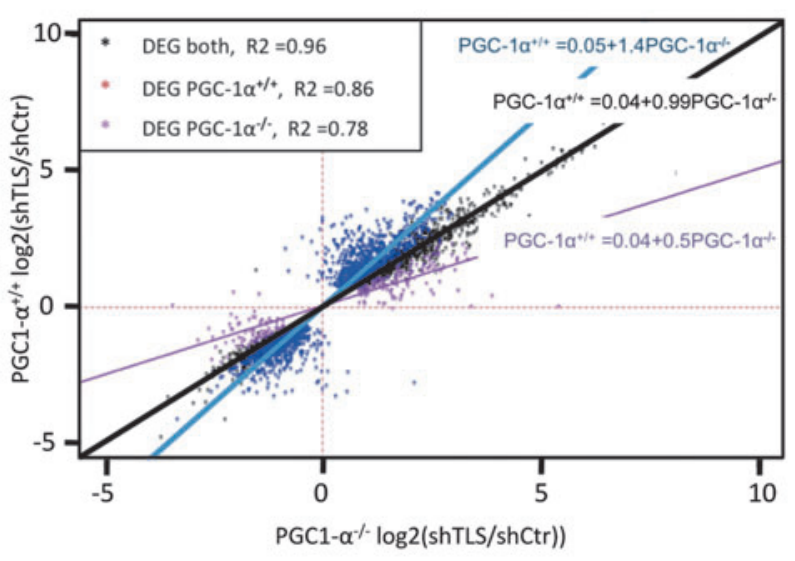

Top 20 down regulated genes shTLS/shControl

\begin{tabular}{|c|c|c|c|c|c|}
\hline Gene & Protein & $\begin{array}{c}\text { PGC1- } \text { - }^{+/ *} \\
\log 2(\mathrm{shTL} / \mathrm{sh} \text { Ctr) }\end{array}$ & Adj $p$ value & $\begin{array}{c}\mathrm{PGC1} 1-\mathrm{a}^{\prime-} \\
\log 2(\mathrm{shTLS} / \mathrm{sh} \mathrm{Ctr})\end{array}$ & Adj $p$ value \\
\hline Cldn2 & claudin-2 & -4.7625 & 0.004847 & -3.6807 & 0.022208 \\
\hline Hsd3b5 & 3-beta-hydroxy-5-ene steroid dehydrogenase & -4.1193 & 0.018085 & -3.3091 & 0.060249 \\
\hline Anks1b & AIDA-1 & -4.0950 & 0.000960 & -2.2200 & 0.032002 \\
\hline $\begin{array}{l}\text { Ubie } \\
\text { C230035/16Rik } \\
\text { Mlph }\end{array}$ & $\begin{array}{l}\text { Ubiquinone } \\
\text { unknown } \\
\text { melanophilin1 }\end{array}$ & $\begin{array}{l}-3.5113 \\
-3.4785 \\
-3.2921 \\
\end{array}$ & $\begin{array}{l}0.001586 \\
0.011074 \\
0.006520 \\
\end{array}$ & $\begin{array}{l}-2.9366 \\
-2.6545 \\
-3.5228 \\
\end{array}$ & $\begin{array}{l}0.005086 \\
0.046782 \\
0.005622 \\
\end{array}$ \\
\hline $\begin{array}{l}\text { Xpnpep2 } \\
\text { Gzmd } \\
\text { 9930111J21Rik } \\
\text { 9530096D07Rik } \\
\text { NAP034039-1 } \\
\end{array}$ & $\begin{array}{l}\text { X-prolyl aminopeptidase } \\
\text { granzime D } \\
\text { unknown } \\
\text { unknown } \\
\text { unknown }\end{array}$ & $\begin{array}{l}-3.2513 \\
-3.2398 \\
-3.1368 \\
-3.1364 \\
-3.1317 \\
\end{array}$ & $\begin{array}{l}0.020283 \\
0.038417 \\
0.040939 \\
0.031196 \\
0.016547\end{array}$ & $\begin{array}{r}0.3243 \\
-1.0964 \\
-0.8222 \\
-1.4899 \\
-1.7915 \\
\end{array}$ & $\begin{array}{l}0.812333 \\
0.462563 \\
0.579582 \\
0.276342 \\
0.141157 \\
\end{array}$ \\
\hline TC1600999 & unknown & -3.0842 & 0.015944 & -2.5310 & 0.050064 \\
\hline $\begin{array}{l}\text { LOC620079 } \\
\text { Lin54 } \\
\text { BC106179 } \\
\text { Mrgprb3 } \\
\text { Plscr3 } \\
\text { Entpd8 } \\
\text { I/3 } \\
\text { Anp32a }\end{array}$ & $\begin{array}{l}\text { unknown } \\
\text { lin-54 homolog (C. elegans) } \\
\text { unknown } \\
\text { MAS-related GPR. member B3 } \\
\text { Phospholipid scramblase } 3 \\
\text { ectonucleoside triphosphate diphosphohydrolase } 8 \\
\text { interleukin-3 } \\
\text { acidic nuclear phasphoprotein } 32 \text { family member A }\end{array}$ & $\begin{array}{l}-3.0761 \\
-3.0692 \\
-3.0238 \\
-3.0181 \\
-3.0156 \\
-2.9935 \\
-2.9876 \\
-2.9588 \\
\end{array}$ & $\begin{array}{l}0.023329 \\
0.021766 \\
0.014602 \\
0.018809 \\
0.003453 \\
0.004123 \\
0.042027 \\
0.029677 \\
\end{array}$ & $\begin{array}{r}0.5971 \\
0.7468 \\
-2.6104 \\
-2.8091 \\
-1.1615 \\
-1.6588 \\
0.0169 \\
-1.2300 \\
\end{array}$ & $\begin{array}{l}0.634634 \\
0.133538 \\
0.038926 \\
0.037460 \\
0.101653 \\
0.068656 \\
0.992510 \\
0.332180 \\
\end{array}$ \\
\hline
\end{tabular}

Top 20 up regulated genes shTLS/shControl

\begin{tabular}{|c|c|c|c|c|c|}
\hline Gene & Protein & $\begin{array}{c}\text { PGC1- } \alpha^{+/ *} \\
\log 2(\operatorname{shTLS} / \text { shCtr) }\end{array}$ & Adj $p$ value & $\begin{array}{c}\text { PGC1- } \text { a }^{k} \\
\log 2(\text { shTLS/shCtr) }\end{array}$ & Adj $p$ value \\
\hline $\begin{array}{l}\text { Sox12 } \\
\text { Cxxc6 }\end{array}$ & $\begin{array}{l}\text { Transcription factor SOX } \\
\text { TET1 }\end{array}$ & $\begin{array}{l}9.5002 \\
6.9569\end{array}$ & $\begin{array}{l}0.32610^{-3} \\
0.09710^{-3}\end{array}$ & $\begin{array}{l}9.1412 \\
6.5895\end{array}$ & $\begin{array}{l}0.41110^{-3} \\
0.13410^{-3}\end{array}$ \\
\hline Cck & Cholecystokinin & 6.8334 & $0.12310^{-3}$ & 0.4568 & 0.781714 \\
\hline $\begin{array}{l}\text { A_52_P877097 } \\
\text { Olfr738 } \\
\text { Fndc8 } \\
\text { TC1719751 } \\
\text { Xcr1 } \\
\end{array}$ & $\begin{array}{l}\text { unknown } \\
\text { olfactory receptor } 738 \\
\text { fibronectin type III domain containing } 8 \\
\text { unknown } \\
\text { Chemokine XC receptor } 1 \\
\end{array}$ & $\begin{array}{l}6.0632 \\
6.0477 \\
5.9647 \\
5.8899 \\
5.8869 \\
\end{array}$ & $\begin{array}{l}0.03710^{-3} \\
0.01610^{-3} \\
0.20710^{-3} \\
0.06310^{-3} \\
0.01010^{-3} \\
\end{array}$ & $\begin{array}{l}6.1319 \\
6.1156 \\
6.2843 \\
5.3262 \\
6.0151 \\
\end{array}$ & $\begin{array}{l}0.03010^{-3} \\
0.01310^{-3} \\
0.12710^{-3} \\
0.11910^{-3} \\
0.00610^{-3} \\
\end{array}$ \\
\hline Gtpbp3 & GTP binding protein 3 & 5.8698 & $0.03710^{-3}$ & -0.4511 & 0.548513 \\
\hline $\begin{array}{l}\text { Unc5d } \\
\text { Tbc1d2 }\end{array}$ & $\begin{array}{l}\text { unc-5 homolog D } \\
\text { TBC1 domain family. member } 21\end{array}$ & $\begin{array}{l}5.8242 \\
5.7955\end{array}$ & $\begin{array}{l}0.50510^{-3} \\
0.02610^{-3}\end{array}$ & $\begin{array}{l}5.5297 \\
5.7119\end{array}$ & $\begin{array}{l}0.71010^{-3} \\
0.02710^{-3}\end{array}$ \\
\hline $\begin{array}{l}\text { Arl10 } \\
\text { Asb7 }\end{array}$ & $\begin{array}{l}\text { ADP-ribosylation factor-like } 101 \\
\text { ankyrin repeat and SOCS box-containing protein } 7\end{array}$ & $\begin{array}{l}5.7743 \\
5.7627\end{array}$ & $\begin{array}{l}0.02610^{-3} \\
0.01610^{-3}\end{array}$ & $\begin{array}{l}-1.0458 \\
-1.0685\end{array}$ & $\begin{array}{l}0.105760 \\
0.140550\end{array}$ \\
\hline $\begin{array}{l}\text { AK036326 } \\
\text { CA481501 } \\
\text { E230015B07Rik } \\
\text { Adprh/1 }\end{array}$ & $\begin{array}{l}\text { unknown } \\
\text { unknown } \\
\text { unknown } \\
\text { ADP-ribosylhydrolase like } 1\end{array}$ & $\begin{array}{l}5.5209 \\
5.5100 \\
5.5002 \\
5.4203\end{array}$ & $\begin{array}{l}0.04410^{-3} \\
0.31810^{-3} \\
0.01010^{-3} \\
0.01610^{-3}\end{array}$ & $\begin{array}{l}5.7643 \\
4.6868 \\
5.4391 \\
5.6044 \\
\end{array}$ & $\begin{array}{l}0.03010^{-3} \\
0.97510^{-3} \\
0.00910^{-3} \\
0.01310^{-3}\end{array}$ \\
\hline Terc & telomerase RNA component & 5.3626 & $0.01610^{-3}$ & -0.6817 & 0.611241 \\
\hline $\begin{array}{l}\text { B230396012Rik } \\
\text { A_51_P516033 }\end{array}$ & $\begin{array}{l}\text { unknown } \\
\text { unknown }\end{array}$ & $\begin{array}{l}5.3510 \\
5.2432\end{array}$ & $\begin{array}{l}0.01610^{-3} \\
0.06510^{-3}\end{array}$ & $\begin{array}{l}5.0655 \\
5.3998\end{array}$ & $\begin{array}{l}0.02010^{-3} \\
0.04310^{-3}\end{array}$ \\
\hline
\end{tabular}

FIG. 6. Genome-wide analysis of TLS gene expression activity and its dependence on PGC-1 $\alpha$. Whole-genome expression arrays were used to evaluate the gene expression changes induced in PGC- $1 \alpha^{+/+}$and PGC- $1 \alpha^{-/-}$hepatocytes by infection with Ad-shTLS or control Ad. (A) The diagrams illustrates the total number of genes differentially down- or upregulated by shTLS in PGC- $1 \alpha^{+/+}$hepatocytes, PGC- $1 \alpha^{-/-}$hepatocytes, or in both. (B) Scatter plot of genes differentially expressed by shTLS: genes shown in blue are genes whose $X$-fold up- or downregulation in PGC-1 $\alpha^{+/+}$hepatocytes is reduced in PGC- $1 \alpha^{-/}$hepatocytes; genes shown in black are similarly regulated in PGC-1 $\alpha^{+/+}$and PGC-1 $\alpha^{-/-}$hepatocytes, and violet indicates genes more strongly regulated in PGC- $1 \alpha^{-/}$hepatocytes. (C) Ingenuity ${ }^{\mathrm{TM}}$ functional distribution of genes differentially regulated in response to shTLS in PGC- $1 \alpha^{+/+}$and PGC- $1 \alpha^{-/-}$hepatocytes. (D) List of the 20 top genes down- and upregulated by shTLS in PGC- $1 \alpha^{+/+}$hepatocytes. The fold change in PGC-1 $\alpha^{+/+}$and PGC-1 $\alpha^{-/-}$hepatocytes, and the corrected $p$-values are indicated. Genes that showed over a two-fold difference in the response to TLS small hairpin RNA (shRNA) in PGC $-1 \alpha^{+/+} /$PGC $-1 \alpha^{-/-}$hepatocytes are shown in green. 
PGC- $1 \alpha$ regulatory networks. The other major function associated with TLS knockdown is cancer and cell cycle control, in line with the previous identification of TLS as a proto-oncogene and a promoter of cell cycle arrest in response to DNA damage (Fig. 6C). Figure 6D lists the top 20 genes down- and upregulated in response to TLS knockdown and their fold change in PGC- $1 \alpha^{+/+}$and PGC- $1 \alpha^{-/-}$hepatocytes.

Since the absence of PGC- $1 \alpha$ decreased TLS activity without any overt effect on TLS expression, we examined whether PGC- $1 \alpha$ influences TLS cellular distribution. Due to its involvement in mRNA transport, TLS normally shuttles between the nucleus and the cytosol (16). Immunofluorescence analysis in PGC- $1 \alpha^{+/+}$hepatocytes confirmed localization of TLS in both the cytosol and the nuclei. The nuclear/cytosol ratio was quite variable between cells within each hepatocyte preparation. Within nuclei, as already described $(3,33)$, TLS was concentrated in nuclear foci. Nuclear foci might be sites of active transcription or mRNA processing and are a classical feature of factors involved in splicing (58). In PGC- $1 \alpha^{-/-}$ hepatocytes, TLS showed a distribution similar to that found in PGC- $1 \alpha^{+/+}$hepatocytes cells (Fig. 7). Suggesting that impaired TLS activity in PGC- $1 \alpha^{-/-}$hepatocytes cannot be attributed to overt changes in TLS subcellular localization.

\section{Discussion}

\section{TLS is a transcriptional coactivator}

TLS is best known as a proto-oncogene, but its normal cellular function is still very poorly characterized. Accumulated data indicate that wild-type TLS plays an important role as a genotoxic sensor in the control of cell-cycle arrest. Understanding the mechanisms of TLS transcriptional activity is made complicated by the protein's multifunctional nature. TLS has been shown to modulate transcriptional initiation, RNA processing, and RNA localization. Moreover, the transcriptional activity of TLS has recently been shown to be modulated by scRNAs bound to its RRM (56). Our results show that TLS is a functional partner of the well-characterized transcriptional cofactor PGC- $1 \alpha$, which is involved in metabolic control, and that TLS transcriptional activity is heavily dependent on PGC- $1 \alpha$. TLS interacts directly with PGC- $1 \alpha$ and increases PGC- $1 \alpha$ transcriptional activity. These two factors cooperate in the regulation of the expression of oxidative stress protection genes, with each dependent on the other for this regulation.

\section{TLS is a genotoxic sensor that regulates the expression of oxidative stress protection genes}

Increased mitochondrial activity results in increased production of ROS that can be harmful to cells. Therefore, induction of antioxidant systems in situations where $\beta$ oxidation is activated is crucial. We previously showed that PGC- $1 \alpha$ coordinates the upregulation of mitochondrial function with increased levels of ROS detoxification enzymes (54), thereby preventing oxidative stress when $\beta$-oxidation is activated. PGC- $1 \alpha$ mRNA expression is in fact induced by ROS via CREB (51). Genotoxic DNA damage is associated with oxidative stress, and is its most deleterious effect. The finding that the DNA damage sensor TLS cooperates with PGC- $1 \alpha$ in the induction of ROS protection genes suggests that PGC- $1 \alpha$ might work as a sensor of oxidative stress-related damage,
IF: TLS
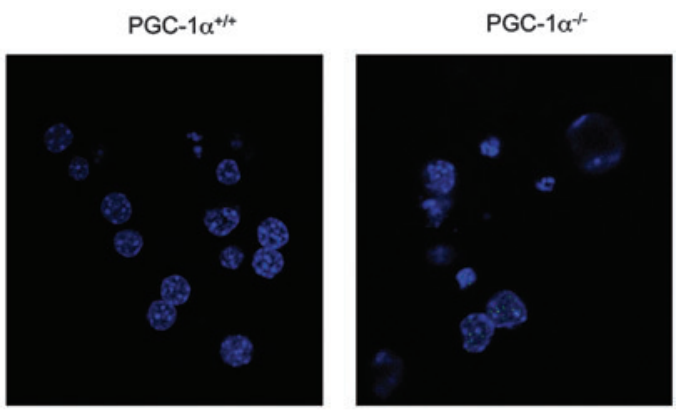

TLS
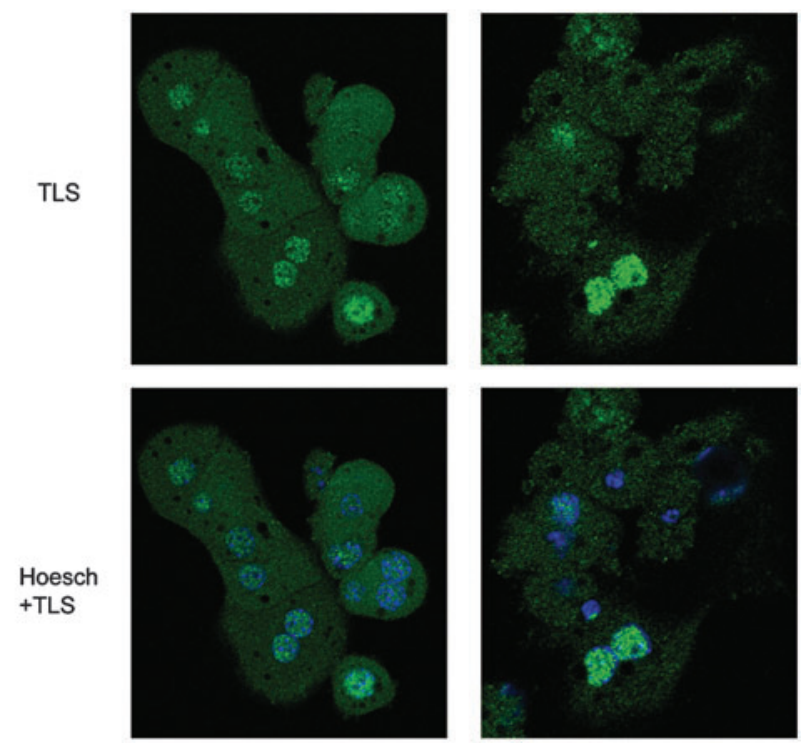

FIG. 7. TLS subcellular localization in PGC- $1 \alpha^{+/+}$and PGC-1 $\alpha^{-/-}$hepatocytes. TLS subcellular localization was analyzed by immunofluorescence with specific antibodies.

and provides a novel link between the genotoxic response and metabolic control.

\section{Hepatocytes as a model system of oxidative stress response}

We carried out this study using hepatocytes as a model system, since liver is a particularly relevant organ when we consider ROS-related pathogenesis since liver plays a central role in metabolic control and its drug-detoxification activities make it a strong producer of ROS. Mitochondrial and ROS related liver dysfunctions are well characterized, and they range from alcohol-induced liver injury to carcinogenesis $(40,57)$

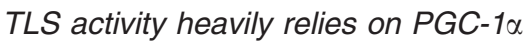

The idea that the genotoxic stress response is linked to general metabolic control is supported by the microarray analysis, which shows that TLS activity modulates both metabolic and cell-control genes, and that TLS regulatory activities are reduced in the absence of PGC- $1 \alpha$. A recent report showed that the DNA damage response protein ATM induces mitochondrial biogenesis, and the authors propose that this induction could be mediated by activation of AMPK (15). Interestingly, ATM has been shown to activate TLS (17), and AMPK is known to activate PGC-1 $\alpha$ (25). 
Oxidative stress and DNA damage responses are regulated by the cellular metabolic status

Findings in organisms ranging from yeast to mammals indicate that poor DNA damage responses and increased oxidative stress are prevalent in situations where $\beta$-oxidation is significantly reduced $(12,47)$. For example, in Saccharomyces cerevisiae (2), Schizosaccharomyces pombe (60), and Caenorhabditis elegans (38), starvation triggers both $\beta$-oxidation and resistance to DNA damage; in mammals, caloric restriction increases the activity of proteins like SirT1 that are known to increase genome stability (18). However, the molecular circuits that link these two functions have remained obscure. Our results are thus the first to identify the interaction and functional dependence of two factors that are key modulators of these regulatory networks.

Other important transcription factors implicated in the regulation of DNA damage and metabolic responses include p53 $(32,45)$ and the sirtuins (particularly SirT1) (14), both of which are activated by oxidative stress $(31,42)$ and have been linked to oxidative stress protection $(23,26)$. Both PGC- $1 \alpha$ and TLS share functions with p53 and sirtuins. For example, both SirT1 and p53 are, like TLS, recruited to sites of DNA damage $(1,36)$. Direct p53-TLS interaction has not been reported, but p53 overexpresion has been identified as a predictor of poor prognosis in myxoid liposarcoma characterized by the presence of the TLS-C /EBP homologous protein oncogenic fusion, suggesting a possible functional connection (4). SirT1 interacts with and deacetylates PGC- $1 \alpha$, regulating its activity (35). Further, p53 knockout mice have reduced numbers of mitochondria and lowered PGC- $1 \alpha$ expression, suggesting a positive role for p53 in the regulation of PGC- $1 \alpha$ activity or expression (46).

The newly found link between TLS and PGC- $1 \alpha$ is therefore an important new contribution to the notion that a variety of stress and metabolic signals converge to activate cell survival or apoptosis. To what extent these responses are activated and what determines the choice between survival and apoptosis are currently intense areas of research.

\section{Materials and Methods}

\section{Cell culture}

Wild-type $\left(\mathrm{TLS}^{+/+}\right)$and $\mathrm{TLS}^{-/-}$MEFs were kindly donated by Dr David Ron (NYU, USA). $\mathrm{TLS}^{+/+}$and $\mathrm{TLS}^{-/-}$ MEFs were maintained in Dulbecco's modified Eagle's medium with $10 \%$ fetal bovine serum (FBS) and antibiotics. Primary hepatocytes were isolated and cultured as previously described $(6,44)$. Briefly, the liver of anesthetized mice was first perfused with perfusion buffer $(150 \mathrm{mM} \mathrm{NaCl}, 5.5 \mathrm{mM}$ $\mathrm{KCl}, 10 \mathrm{mM}$ HEPES pH 7.5, $25 \mathrm{mM} \mathrm{NaHCO}$, and $0.5 \mathrm{mM}$ EGTA) and then with $0.05 \%$ collagenase for $10 \mathrm{~min}$. Dispersed cells were seeded onto collagen-coated plates $(0.2 \%$ gelatin, $1 \%$ collagen) and cultured in Williams E Medium (Gibco) supplemented with $10 \%$ FBS, $2 \mathrm{mM}$ L-glutamine, $100 \mathrm{nM}$ dexamethasone, $100 \mathrm{nM}$ insulin, and antibiotics. Fresh medium was added $4 \mathrm{~h}$ after plating. C57BL6 PGC- $1 \alpha^{-/-}$mice were originally provided by Dr. Bruce Spiegelman (DFCI) and following embryonic transfer a colony was established within the SPF area of the CNIC animal facility. Female C57BL6 PGC- $1 \alpha^{+/+}$ and PGC- $1 \alpha^{-/-}$of $8-10$ weeks of age were used. The animal experimental protocols were approved by the Institutional
Animal Care and Use Committee of the CNIC. All procedures conformed to the Declaration of Helsinki and the NIH guidelines for animal care and use (NIH publication No. 85-23). The rat hepatoma cell line FAO was grown in RPMI medium supplemented with 10\% FBS, 2 mM L-glutamine, and antibiotics. 293T cells were maintained in Dulbecco's modified Eagle's medium with 10\% FBS and antibiotics.

\section{Yeast two-hybrid screen}

A yeast two-hybrid screen was carried out with the Matchmaker Two-Hybrid System (Clontech). The PGC-1 $\alpha$ CTD (aa 561-797) was cloned in the EcoR1-BamHI sites of pGBKT7 and used as bait to screen human cDNAs fused to the Gal4 transcriptional activation domain in the GADT7 vector. Thirty-two positive colonies were selected, confirmed, and sequenced. Three clones were found to correspond to the TLS gene.

\section{Adenoviral infections}

FAO cells, MEF, and hepatocytes were infected overnight with adenoviral vectors at a moi of $1-50$. Viruses were washed off and cells were harvested 24 or $48 \mathrm{~h}$ postinfection.

mRNA and protein were analyzed by quantitative PCR of retro transcribed cDNA (qRT-PCR) and WB. The primers and antibodies used were as described $(9,37,54)$. Polyclonal $\alpha$-TLS antibody for WB was from Novus Biologicals. TLS-specific primers for qRT-PCR were forward 5'-CCGATACCT GTCGTCTTGGTC-3' and reverse 5'- CCTCCACCACCGC CACCTCCT-3'.

\section{Immunoprecipitation and ChIP}

Preparation of whole-cell extracts and immunoprecipitation (IP) were carried out as described (34). Experimental conditions for ChIP were as previously described (54). TLS was immunoprecipitated with a monoclonal $\alpha$-TLS antibody (BD Biosciences). Coprecipitated DNA was analyzed by qPCR using primer pairs listed in the Supplementary Data (Supplementary Table S1). Oligos designed against the coding sequence of $\beta$-actin were used as negative control.

\section{Luciferase reporter assays}

MEF and FAO were transfected with plasmids (Lipofectamine $2000^{\mathrm{TM}}$ ) for $8 \mathrm{~h}$ according to the manufacturer's instructions. Twenty-four hours post-transfection, luciferase activity was determined with the Dual-luciferase ${ }^{\circledR}$ Reporter Assay System (Promega).

\section{GST-pull down assays}

Recombinant GST fusion proteins were expressed from pGEX expression vectors in E. coli (strain B121-DE3) and were purified with glutathione agarose (Pharmacia Biotech). Target proteins were labeled with ${ }^{35} \mathrm{~S}$-methionine by in vitro transcription/translation using the TNT system (Promega). Labeled proteins were incubated for $1 \mathrm{~h}$ at RT with $1 \mu \mathrm{g}$ GST fusion protein immobilized on $20 \mu \mathrm{l}$ agarose beads in $200 \mu \mathrm{l}$ of binding buffer (20 M Tris- $\mathrm{HCl}$ [pH 8.0], 10\% glycerol, $5 \mathrm{mM}$ $\mathrm{MgCl}_{2}, 0.5 \mathrm{mM}$ EDTA, $0.5 \mathrm{mM}$ EGTA, $2 \mathrm{mM}$ DTT, $0.1 \%-0.4 \%$ $\mathrm{NP}-40$, and $100 \mathrm{mM} \mathrm{KCl}$ ). Beads were washed three times with $1 \mathrm{ml}$ binding buffer. Bound proteins were analyzed by SDS-PAGE and autoradiography. 


\section{Reactive oxygen species}

Cells were labeled with $\mathrm{CM}-\mathrm{H}_{2}$ DCFDA. ROS levels were determined by flow cytometry as described (54).

\section{Caspase-3 activity}

Fluorimetric quantification of caspase-3 activity was as previously described (54).

\section{Statistics}

Data are expressed as means \pm SD. Statistical significance was evaluated by analysis of variance or a nonparametric test, as appropriate. Values were considered statistically significant at $p<0.05$. $n \geq 3$ in all experiments.

\section{Acknowledgments}

We thank Dr. S. Drori for the two-hybrid screen. Dr. D.D. Hickstein for pSG5-FL-TLS, Dr. T. Okamoto for pGEX-TLS, Dr. B. Spigelman for PGC- $1 \alpha^{-/-}$mice, Dr. D. Ron for TLS ${ }^{-/-}$ MEFs, and Dr. J. Sastre for careful reading of the article. Editorial support was provided by Dr. S. Bartlett. This work was supported by the Spanish Ministry of Science and Innovation (grants SAF2006-01619, SAF2009-07599, and CSD 2007-00020 to M.M.; an FPI predoctoral fellowship to C.S.R.; a Juan de la Cierva postdoctoral contract to A.T.) and by the CNIC (CICERONE student fellowship to O.F.). The CNIC is supported by the Spanish Ministry of Science and Innovation and the Pro-CNIC Foundation.

\section{Author Disclosure Statement}

No competing financial interests exist.

\section{References}

1. Al Rashid ST, Dellaire G, Cuddihy A, Jalali F, Vaid M, Coackley C, Folkard M, Xu Y, Chen BP, Chen DJ, Lilge L, Prise KM, Bazett Jones DP, and Bristow RG. Evidence for the direct binding of phosphorylated p53 to sites of DNA breaks in vivo. Cancer Res 65: 10810-10821, 2005.

2. Albers E, Larsson C, Andlid T, Walsh MC, and Gustafsson L. Effect of nutrient starvation on the cellular composition and metabolic capacity of Saccharomyces cerevisiae. Appl Environ Microbiol 73: 4839-4848, 2007.

3. Alliegro MC and Alliegro MA. A nuclear protein regulated during the transition from active to quiescent phenotype in cultured endothelial cells. Dev Biol 174: 288-297, 1996.

4. Antonescu CR, Tschernyavsky SJ, Decuseara R, Leung DH, Woodruff JM, Brennan MF, Bridge JA, Neff JR, Goldblum JR, and Ladanyi M. Prognostic impact of P53 status, TLSCHOP fusion transcript structure, and histological grade in myxoid liposarcoma: a molecular and clinicopathologic study of 82 cases. Clin Cancer Res 7: 3977-3987, 2001.

5. Baechtold H, Kuroda M, Sok J, Ron D, Lopez BS, and Akhmedov AT. Human 75-kDa DNA-pairing protein is identical to the pro-oncoprotein TLS/FUS and is able to promote Dloop formation. J Biol Chem 274: 34337-34342, 1999.

6. Bahjat FR, Dharnidharka VR, Fukuzuka K, Morel L, Crawford JM, Clare-Salzler MJ, and Moldawer LL. Reduced susceptibility of nonobese diabetic mice to TNF-alpha and D-galactosamine-mediated hepatocellular apoptosis and lethality. J Immunol 165: 6559-6567, 2000.
7. Bertolotti A, Bell B, and Tora L. The N-terminal domain of human TAFII68 displays transactivation and oncogenic properties. Oncogene 18: 8000-8010, 1999.

8. Bertrand P, Akhmedov AT, Delacote F, Durrbach A, and Lopez BS. Human POMp75 is identified as the prooncoprotein TLS/FUS: both POMp75 and POMp100 DNA homologous pairing activities are associated to cell proliferation. Oncogene 18: 4515-4521, 1999.

9. Borniquel S, Valle I, Cadenas S, Lamas S, and Monsalve M. Nitric oxide regulates mitochondrial oxidative stress protection via the transcriptional coactivator PGC-1alpha. FASEB J 20: 1889-1891, 2006.

10. Bouvet P, Diaz JJ, Kindbeiter K, Madjar JJ, and Amalric F. Nucleolin interacts with several ribosomal proteins through its RGG domain. J Biol Chem 273: 19025-19029, 1998.

11. Burd CG and Dreyfuss G. RNA binding specificity of hnRNP A1: significance of hnRNP A1 high-affinity binding sites in pre-mRNA splicing. EMBO J 13: 1197-1204, 1994.

12. Burhans WC and Heintz NH. The cell cycle is a redox cycle: linking phase-specific targets to cell fate. Free Radic Biol Med 47: 1282-1293, 2009.

13. Cartegni L, Maconi M, Morandi E, Cobianchi F, Riva S, and Biamonti G. hnRNP A1 selectively interacts through its Glyrich domain with different RNA-binding proteins. J Mol Biol 259: 337-348, 1996.

14. Finkel T, Deng CX, and Mostoslavsky R. Recent progress in the biology and physiology of sirtuins. Nature 460: 587-591, 2009.

15. Fu X, Wan S, Lyu YL, Liu LF, and Qi H. Etoposide induces ATM-dependent mitochondrial biogenesis through AMPK activation. PLoS One 3: e2009, 2008.

16. Fujii $\mathrm{R}$ and Takumi T. TLS facilitates transport of mRNA encoding an actin-stabilizing protein to dendritic spines. $J$ Cell Sci 118: 5755-5765, 2005.

17. Gardiner M, Toth R, Vandermoere F, Morrice NA, and Rouse J. Identification and characterization of FUS/TLS as a new target of ATM. Biochem J 415: 297-307, 2008.

18. Ghosh HS. The anti-aging, metabolism potential of SIRT1. Curr Opin Investig Drugs 9: 1095-1102, 2008.

19. Hallier M, Lerga A, Barnache S, Tavitian A, and MoreauGachelin F. The transcription factor Spi-1/PU.1 interacts with the potential splicing factor TLS. J Biol Chem 273: 4838-4842, 1998.

20. Handschin C. The biology of PGC-1alpha and its therapeutic potential. Trends Pharmacol Sci 30: 322-329, 2009.

21. Hicks GG, Singh N, Nashabi A, Mai S, Bozek G, Klewes L, Arapovic D, White EK, Koury MJ, Oltz EM, Van Kaer L, and Ruley HE. Fus deficiency in mice results in defective Blymphocyte development and activation, high levels of chromosomal instability and perinatal death. Nat Genet 24: 175-179, 2000.

22. Horvathova E, Eckl PM, Bresgen N, and Slamenova D. Evaluation of genotoxic and cytotoxic effects of $\mathrm{H}_{2} \mathrm{O}_{2}$ and DMNQ on freshly isolated rat hepatocytes; protective effects of carboxymethyl chitin-glucan. Neuro Endocrinol Lett 29: 644-648, 2008.

23. Hussain SP, Amstad P, He P, Robles A, Lupold S, Kaneko I, Ichimiya M, Sengupta S, Mechanic L, Okamura S, Hofseth LJ, Moake M, Nagashima M, Forrester KS, and Harris CC. p53-induced up-regulation of MnSOD and GPx but not catalase increases oxidative stress and apoptosis. Cancer Res 64: 2350-2356, 2004.

24. Iko Y, Kodama TS, Kasai N, Oyama T, Morita EH, Muto T, Okumura M, Fujii R, Takumi T, Tate S, and Morikawa K. 
Domain architectures and characterization of an RNAbinding protein, TLS. J Biol Chem 279: 44834-44840, 2004.

25. Jager S, Handschin C, St-Pierre J, and Spiegelman BM. AMPactivated protein kinase (AMPK) action in skeletal muscle via direct phosphorylation of PGC-1alpha. Proc Natl Acad Sci U S A 104: 12017-12022, 2007.

26. Kobayashi Y, Furukawa-Hibi Y, Chen C, Horio Y, Isobe K, Ikeda K, and Motoyama N. SIRT1 is critical regulator of FOXO-mediated transcription in response to oxidative stress. Int J Mol Med 16: 237-243, 2005.

27. Kuroda M, Sok J, Webb L, Baechtold H, Urano F, Yin Y, Chung P, de Rooij DG, Akhmedov A, Ashley T, and Ron D. Male sterility and enhanced radiation sensitivity in TLS(-/-) mice. EMBO J 19: 453-462, 2000.

28. Law WJ, Cann KL, and Hicks GG. TLS, EWS and TAF15: a model for transcriptional integration of gene expression. Brief Funct Genomic Proteomic 5: 8-14, 2006.

29. Lerga A, Hallier M, Delva L, Orvain C, Gallais I, Marie J, and Moreau-Gachelin F. Identification of an RNA binding specificity for the potential splicing factor TLS. J Biol Chem 276: 6807-6816, 2001.

30. Li X, Monks B, Ge Q, and Birnbaum MJ. Akt/PKB regulates hepatic metabolism by directly inhibiting PGC-1alpha transcription coactivator. Nature 447: 1012-1016, 2007.

31. Lotem J, Peled-Kamar M, Groner Y, and Sachs L. Cellular oxidative stress and the control of apoptosis by wild-type p53, cytotoxic compounds, and cytokines. Proc Natl Acad Sci U S A 93: 9166-9171, 1996.

32. Meek DW. Tumour suppression by p53: a role for the DNA damage response? Nat Rev Cancer 9: 714-723, 2009.

33. Meissner M, Lopato S, Gotzmann J, Sauermann G, and Barta A. Proto-oncoprotein TLS/FUS is associated to the nuclear matrix and complexed with splicing factors PTB, SRm160, and SR proteins. Exp Cell Res 283: 184-195, 2003.

34. Monsalve M, Wu Z, Adelmant G, Puigserver P, Fan M, and Spiegelman BM. Direct coupling of transcription and mRNA processing through the thermogenic coactivator PGC-1. Mol Cell 6: 307-316, 2000.

35. Nemoto S, Fergusson MM, and Finkel T. SIRT1 functionally interacts with the metabolic regulator and transcriptional coactivator PGC-1\{alpha\}. J Biol Chem 280: 16456-16460, 2005.

36. Oberdoerffer P, Michan S, McVay M, Mostoslavsky R, Vann J, Park SK, Hartlerode A, Stegmuller J, Hafner A, Loerch P, Wright SM, Mills KD, Bonni A, Yankner BA, Scully R, Prolla TA, Alt FW, and Sinclair DA. SIRT1 redistribution on chromatin promotes genomic stability but alters gene expression during aging. Cell 135: 907-918, 2008.

37. Olmos Y, Valle I, Borniquel S, Tierrez A, Soria E, Lamas S, and Monsalve M. Mutual dependence of Foxo3a and PGC1alpha in the induction of oxidative stress genes. J Biol Chem 284: 14476-14484, 2009.

38. Panowski SH and Dillin A. Signals of youth: endocrine regulation of aging in Caenorhabditis elegans. Trends Endocrinol Metab 20: 259-264, 2009.

39. Perrotti D, Bonatti S, Trotta R, Martinez R, Skorski T, Salomoni P, Grassilli E, Lozzo RV, Cooper DR, and Calabretta B. TLS/FUS, a pro-oncogene involved in multiple chromosomal translocations, is a novel regulator of $\mathrm{BCR} / \mathrm{ABL}$ mediated leukemogenesis. EMBO J 17: 4442-4455, 1998.

40. Pessayre D, Mansouri A, Berson A, and Fromenty B. Mitochondrial involvement in drug-induced liver injury. Handb Exp Pharmacol: 311-365, 2010.

41. Powers CA, Mathur M, Raaka BM, Ron D, and Samuels HH. TLS (translocated-in-liposarcoma) is a high-affinity inter- actor for steroid, thyroid hormone, and retinoid receptors. Mol Endocrinol 12: 4-18, 1998.

42. Prozorovski T, Schulze-Topphoff U, Glumm R, Baumgart J, Schroter F, Ninnemann O, Siegert E, Bendix I, Brustle O, Nitsch R, Zipp F, and Aktas O. Sirt1 contributes critically to the redox-dependent fate of neural progenitors. Nat Cell Biol 10: 385-394, 2008.

43. Puigserver P, Rhee J, Donovan J, Walkey CJ, Yoon JC, Oriente F, Kitamura Y, Altomonte J, Dong H, Accili D, and Spiegelman BM. Insulin-regulated hepatic gluconeogenesis through FOXO1-PGC-1alpha interaction. Nature 423: 550-555, 2003.

44. Rana B, Mischoulon D, Xie Y, Bucher NL, and Farmer SR. Cell-extracellular matrix interactions can regulate the switch between growth and differentiation in rat hepatocytes: reciprocal expression of C/EBP alpha and immediate-early growth response transcription factors. Mol Cell Biol 14: 58585869, 1994.

45. Sahin E and Depinho RA. Linking functional decline of telomeres, mitochondria and stem cells during ageing. Nature 464: 520-528, 2010.

46. Saleem A, Adhihetty PJ, and Hood DA. Role of p53 in mitochondrial biogenesis and apoptosis in skeletal muscle. Physiol Genomics 37: 58-66, 2009.

47. Seyfried TN and Shelton LM. Cancer as a metabolic disease. Nutr Metab (Lond) 7: 7, 2010.

48. Shin DJ, Campos JA, Gil G, and Osborne TF. PGC-1alpha activates CYP7A1 and bile acid biosynthesis. J Biol Chem 278: 50047-50052, 2003.

49. Simbula G, Columbano A, Ledda-Columbano GM, Sanna L, Deidda M, Diana A, and Pibiri M. Increased ROS generation and p53 activation in alpha-lipoic acid-induced apoptosis of hepatoma cells. Apoptosis 12: 113-123, 2007.

50. Speckmann B, Walter PL, Alili L, Reinehr R, Sies H, Klotz $\mathrm{LO}$, and Steinbrenner H. Selenoprotein P expression is controlled through interaction of the coactivator PGC-1alpha with FoxO1a and hepatocyte nuclear factor 4alpha transcription factors. Hepatology 48: 1998-2006, 2008.

51. St-Pierre J, Drori S, Uldry M, Silvaggi JM, Rhee J, Jager S, Handschin C, Zheng K, Lin J, Yang W, Simon DK, Bachoo R, and Spiegelman BM. Suppression of reactive oxygen species and neurodegeneration by the PGC-1 transcriptional coactivators. Cell 127: 397-408, 2006.

52. Tan AY and Manley JL. The TET family of proteins: functions and roles in disease. J Mol Cell Biol 1: 82-92, 2009.

53. Uranishi H, Tetsuka T, Yamashita M, Asamitsu K, Shimizu M, Itoh $\mathrm{M}$, and Okamoto $\mathrm{T}$. Involvement of the pro-oncoprotein TLS (translocated in liposarcoma) in nuclear factor-kappa B p65-mediated transcription as a coactivator. J Biol Chem 276: 13395-13401, 2001.

54. Valle I, Alvarez-Barrientos A, Arza E, Lamas S, and Monsalve M. PGC-1alpha regulates the mitochondrial antioxidant defense system in vascular endothelial cells. Cardiovasc Res 66: 562-573, 2005.

55. Vousden KH and Ryan KM. p53 and metabolism. Nat Rev Cancer 9: 691-700, 2009.

56. Wang X, Arai S, Song X, Reichart D, Du K, Pascual G, Tempst P, Rosenfeld MG, Glass CK, and Kurokawa R. Induced ncRNAs allosterically modify RNA-binding proteins in cis to inhibit transcription. Nature 454: 126-130, 2008.

57. $\mathrm{Wu} \mathrm{D}$ and Cederbaum AI. Oxidative stress and alcoholic liver disease. Semin Liver Dis 29: 141-154, 2009.

58. Yang L, Embree LJ, Tsai S, and Hickstein DD. Oncoprotein TLS interacts with serine-arginine proteins involved in RNA splicing. J Biol Chem 273: 27761-27764, 1998. 
59. Zinszner $\mathrm{H}$, Albalat $\mathrm{R}$, and Ron $\mathrm{D}$. A novel effector domain from the RNA-binding protein TLS or EWS is required for oncogenic transformation by CHOP. Genes Dev 8: 2513-2526, 1994.

60. Zuin A, Carmona M, Morales-Ivorra I, Gabrielli N, Vivancos AP, Ayte J, and Hidalgo E. Lifespan extension by calorie restriction relies on the Sty1 MAP kinase stress pathway. EMBO J 29: 981-991.

Address correspondence to: Dr. María Monsalve Centro Nacional de Investigaciones Cardiovasculares Melchor Fernández Almagro 3, Room S2 Madrid 28029

Spain

E-mail: mmonsalve@cnic.es

Date of first submission to ARS Central, September 14, 2010; date of final revised submission, February 14, 2011; date of acceptance, February 19, 2011.

\begin{tabular}{rl|} 
& Abbreviations Used \\
$\mathrm{Ad}=$ & adenovirus \\
$\mathrm{Ad}-\mathrm{P}=$ & recombinant adenovirus encoding PGC- $1 \alpha$ \\
$\mathrm{Ad}-\mathrm{T}=$ & recombinant adenovirus encoding TLS \\
$\mathrm{ATM}=$ & ataxia telangiectasia mutated \\
$\mathrm{ATPase} \beta=$ & $\mathrm{ATP}$ synthetase $\beta$ subunit \\
$\mathrm{ChIP}=$ & chromatin immunoprecipitation \\
$\mathrm{CM}-\mathrm{H}_{2} \mathrm{DCFDA}=$ & 5 -chloromethyl-2' $7^{\prime}$-dichlorodi- \\
& hydrofluorescein diacetate acetyl ester
\end{tabular}

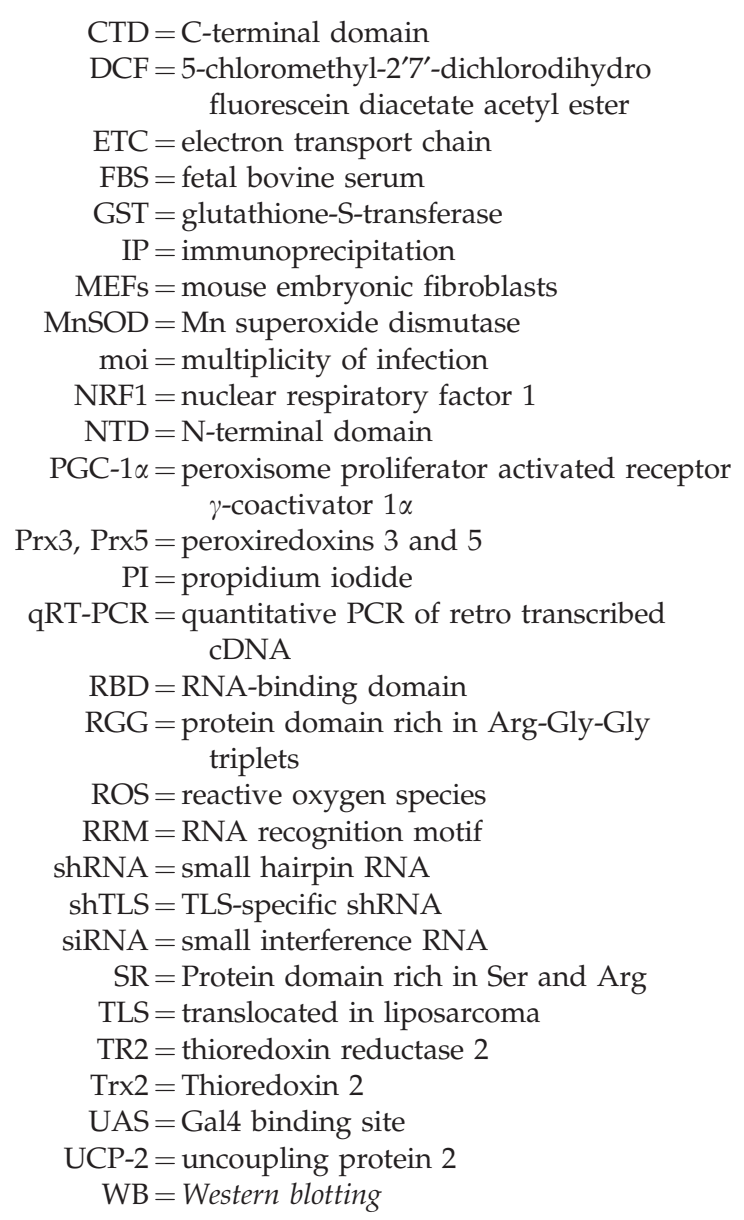


